\title{
A CHROMOSOME 21-SPECIFIC COSMID COCKTAIL FOR THE DETECTION OF CHROMOSOME 21 ABERRATIONS IN INTERPHASE NUCLEI
}

\author{
DLANE VAN OPSTAL, JAN O. VAN HEMEL, BERT H. J. EUSSEN, ANNET VAN DER HEIDE, CARDI VAN DEN BERG, \\ PETER A. IN 'T VELD AND FRANS J. LOS \\ Department of Clinical Genetics, University Hospital Dijkzigt, Erasmus University, Rotterdam, The Netherlands \\ Received 9 January 1995 \\ Revised 27 March 1995 \\ Accepted 11 April 1995
}

\section{SUMMARY}

Fluorescent in situ hybridization (FISH) with a 21q11-specific probe (CB21cl) consisting of three non-overlapping cosmids has been applied to interphase amniocytes of pregnancies at increased risk for fetal aneuploidy $(N=78)$ and to interphase lymphocytes, cultured and uncultured, of patients referred for Down syndrome ( $N=19$ and 28 , respectively). In the uncultured amniocytes, six chromosome aberrations were detected: three cases of trisomy 21 , a triploidy, a de novo 46,XX,t(2lq21q), and a mosaic 46,XY/47,XY, $+\operatorname{dic}(21)(\mathrm{q} 11) / 48, \mathrm{XY},+\operatorname{dic}(21)(\mathrm{q} 11)$, $+\operatorname{del}(21)(q 11)$. In 15 cultured and 20 uncultured blood samples, FISH correctly diagnosed trisomy 21 (full or mosaic) at the interphase level, which was confirmed in all cases by subsequent karyotyping. Because of specific and strong signals in interphase nuclei, CB21cl appears to be a useful tool for the rapid detection of chromosome 21 abnormalities.

KEY WORDS: interphase cytogenetics; $21 \mathrm{q} 11$ cosmids; uncultured amniocytes; mosaic trisomy 21 ; translocation (2lq21q)

\section{INTRODUCTION}

Fluorescent in situ hybridization (FISH) has proven to be a powerful method for the rapid detection of chromosomal aneuploidies in uncultured amniocytes (Klinger et al., 1992; Van Opstal et al., 1993), in uncultured mesenchymal chorionic villus cells (Bryndorf et al,, 1994), in fetal cells circulating in maternal blood (Gänshirt-Ahlert et al. 1993), and in pre-embryonic blastomeres (Munné et al., 1994). The reliability of this technique depends highly on the specificity and the hybridization efficiency of the probes. Centromeric repetitive alphoid DNA probes are often applied for interphase cytogenetics as they produce strong

Addressee for correspondence: Diane Van Opstal, Department of Clinical Genetics, University Hospital Dijkzigt, Erasmus University, P.O. Box 1738, 3000 DR Rotterdam, The Netherlands. signals. However, for the detection of the most frequently encountered chromosome abnormality in prenatal diagnosis, trisomy 21 , only the probe L1.26 (Devilee et al., 1986) is available. This probe has been reported to be successful for the detection of trisomy 21 by several authors (Zahed et al., 1992; Lebo et al., 1992; Rao et al., 1993). However, others showed that this probe was not reliable, as the copy number of the sequence recognized by the probe is a highly polymorphic trait and sometimes appears to be too small to produce any signal, which resulted in false-negative outcomes (Verma and Luke, 1992; Mizouno and Young, 1992; SeresSantamaria et al., 1993; Cacheux et al., 1994). Moreover, L1.26 cross-hybridizes to the centromeric region of chromosome 13, which does not allow distinction between trisomy 21 and trisomy 13. For both reasons, we investigated the utility of the present 21q11 cosmid cocktail, CB21cl, for its applicability in pre- and postnatal diagnosis. 


\section{MATERIALS AND METHODS}

\section{Cell preparations}

Amniocentesis was performed because of advanced maternal age ( $\geq 40$ years) $(N=14)$ and ultrasound abnormalities $(N=61)$, and confirmation of trisomy 21 mosaicism $(N=2)$ and of a de novo translocation $(21 \mathrm{q} 21 \mathrm{q})$ in previous direct chorionic villi. From routine amniotic fluid samples, one slide was prepared directly (Van Opstal et al., 1993) for hybridization with the present 21-probe and the remainder were cultured by the in situ method for cytogenetic analysis. Metaphase spreads of lymphocytes were prepared according to standard techniques. Interphase nuclei of uncultured lymphocytes were obtained by incubating the cells in $0.075 \mathrm{M} \mathrm{KCl}$ at $37^{\circ} \mathrm{C}$ for $18 \mathrm{~min}$. Subsequently, the cells were fixed by three changes of methanol-acetic acid (3:1) and dropped onto slides. Routine trypsin-Giemsa banding was applied for cytogenetic analysis of the cultured amniotic fluid cells and the lymphocytes.

The pretreatment of the slides consisted of an RNase (Pharmacia) treatment $(100 \mu \mathrm{g} / \mathrm{ml}$ in $2 \times \mathrm{SSC}$ ) at $37^{\circ} \mathrm{C}$ for $1 \mathrm{~h}$, followed by a pepsin (Serva or Sigma) treatment $(4 \mathrm{mg} / \mathrm{ml}$ for amniocytes and $100 \mu \mathrm{g} / \mathrm{ml}$ for lymphocytes) in $0.01 \mathrm{M}$ $\mathrm{HCl}$ at $37^{\circ} \mathrm{C}$ for $15 \mathrm{~min}$. Uncultured amniotic fluid preparations were post-fixed in 3.7 per cent formaldehyde (Merck) in phosphate-buffered saline (PBS) for $10 \mathrm{~min}$.

\section{DNA probe and labelling}

The 21 cosmid cocktail, CB21c1, consists of three non-overlapping cosmids, ICRFc102B02134, ICRFc102B11128, and ICRFc102C0755, which map to the D21S13 locus at 21q11 (Stinissen et al., 1990; Stinissen and Van Broeckhoven, 1991). The probes were labelled with biotin-11-dUTP by nick translation with the BioNick system (Gibco BRL).

\section{Probe detection and signal analysis}

The hybridization mixture, consisting of 50 per cent formamide (Merck) $/ 2 \times$ SSC, 10 per cent dextran sulphate (Pharmacia), 1 per cent Tween-20 (Bio Rad), $5 \mu \mathrm{g}$ of salmon sperm DNA (Sigma), $5 \mu \mathrm{g}$ of tRNA (Gibco BRL), $1 \mu \mathrm{g}$ of Cot-1 DNA (Gibco BRL), and $32 \mathrm{ng}$ of each of the three biotinylated probes, was denatured at $90^{\circ} \mathrm{C}$ for $5 \mathrm{~min}$ and immediately put on ice, followed by $1 \mathrm{~h}$ preannealing at $37^{\circ} \mathrm{C}$. Target
DNA on the siides was denatured by immersion in 70 per cent formamide $2 \times \mathrm{SSC}$ for $3 \mathrm{~min}$ at $80^{\circ} \mathrm{C}$ and dehydrated in an ethanol series. The hybridization reaction was performed overnight at $37^{\circ} \mathrm{C}$.

After hybridization, the slides were washed three times in 50 per cent formamide $2 \times \mathrm{SSC}$ at $42-45^{\circ} \mathrm{C}$ for $5 \mathrm{~min}$, followed by three changes of $2 \times \mathrm{SSC}$, twice at $42-45^{\circ} \mathrm{C}$ and once at $60-65^{\circ} \mathrm{C}$. They were treated with alternating layers of fluoresceinated avidin and biotinylated goat antiavidin (Vector Labs), and finally the slides were mounted in $0.2 \mathrm{M}$ Tris-HCl/glycerol $(1: 9 \mathrm{v} / \mathrm{v}$, pH 7.5) containing 2 per cent DABCO (Sigma) and the fluorescent counterstains propidium iodide $(0.5 \mu \mathrm{g} / \mathrm{ml})$ and DAPI $(0.25 \mu \mathrm{g} / \mathrm{ml})$. Coded slides were examined under a Leica Aristoplan epifluorescence equipped microscope and images were captured with the Genetiscan ProbeMaster system (Perceptive Scientific International Ltd. (PSI), Chester, U.K.) including a Xybion cooled CCD 24-bit colour camera. One hundred lymphocytes and a mean of 41 (range 10-84) amniocytes were counted in each case. Nuclei without signals were not included in the data.

\section{RESULTS}

FISH was performed on interphase nuclei of cultured $(N=19)$ and uncultured $(N=28)$ blood samples and of uncultured amniotic fluid samples $(N=78)$. The signal distributions in cultured and uncultured lymphocytes are shown in Tables I and II, respectively. More than 99 per cent of the nuclei showed compact and bright signals (Fig. 1a). Separate spots per signal, produced by each of the three cosmids in the cocktail, were sometimes noticed in the largest cultured cells (Fig. 1b). The signal distributions allowed a clear discrimination between normal samples and samples with trisomy 21 (full as well as mosaic).

Although the number of analysable nuclei varied among the uncultured amniotic fluid samples (mean 41, range 10-84), their distributions did suggest six chromosome 21 aberrations (Table III). Karyotyping of the cultured cells revealed full trisomy 21 in three cases (Fig. 1c), a triploidy, and a de novo unbalanced translocation (21q21q) (Fig. 1d). In the sixth case with 23 per cent of the uncultured cells showing two signals and 77 per cent three to six signals (Fig. 1e), subsequent chromosome analysis of the cell cultures revealed 
Table I-Signal distributions after EISH with CB21c1 in 19 samples of cultured lymphocytes

\begin{tabular}{|c|c|c|c|c|c|}
\hline \multirow{2}{*}{$\begin{array}{l}\text { No. } \\
\text { of cases }\end{array}$} & \multicolumn{4}{|c|}{ Mean percentage (range) of nuclei showing 1-4 signals } & \multirow[b]{2}{*}{ Karyotype } \\
\hline & 1 & 2 & 3 & 4 & \\
\hline 4 & $\begin{array}{c}3 \\
(2-4)\end{array}$ & $\begin{array}{c}89 \\
(83-95)\end{array}$ & $\begin{array}{c}8 \\
(3-12)\end{array}$ & 0 & $46,-^{*}$ \\
\hline 13 & $\begin{array}{c}2 \\
(0-6)\end{array}$ & $\begin{array}{c}12 \\
(4-24)\end{array}$ & $\begin{array}{c}84 \\
(68-94)\end{array}$ & $\begin{array}{c}2 \\
(0-6)\end{array}$ & $47,-^{*},+21$ \\
\hline 1 & 3 & 48 & 47 & 1 & Mos $46, \mathrm{XX} / 47, \mathrm{XX},+21(21 / 79)$ \\
\hline 1 & 0 & 79 & 21 & 0 & Mos $46, \mathrm{XX} / 47, \mathrm{XX},+21(82 / 18)$ \\
\hline
\end{tabular}

*-XX or $\mathrm{XY}$

Table II-Signal distributions after FISH with CB21c1 in 28 samples of uncultured lymphocytes

\begin{tabular}{|c|c|c|c|c|c|}
\hline \multirow{2}{*}{$\begin{array}{l}\text { No. } \\
\text { of cases }\end{array}$} & \multicolumn{4}{|c|}{ Mean percentage (range) of nuclei showing 1-4 signals } & \multirow[b]{2}{*}{ Karyotype } \\
\hline & 1 & 2 & 3 & 4 & \\
\hline 8 & $\begin{array}{c}9 \\
(1-18)\end{array}$ & $\begin{array}{c}85 \\
(78-99)\end{array}$ & $\begin{array}{c}5 \\
(0-8)\end{array}$ & $\begin{array}{c}1 \\
(0-4)\end{array}$ & 46, - $^{*}$ \\
\hline 18 & $\begin{array}{c}1 \\
(0-4)\end{array}$ & $\begin{array}{c}15 \\
(4-35)\end{array}$ & $\begin{array}{c}81 \\
(61-93)\end{array}$ & $\begin{array}{c}3 \\
(0-10)\end{array}$ & $47,-^{*},+21$ \\
\hline 1 & 5 & 52 & 43 & 0 & $\operatorname{Mos} 46, \mathrm{XX} / 47, \mathrm{XX},+21(64 / 36)$ \\
\hline 1 & 0 & 21 & 79 & 0 & Mos 46,XY/47,XY,+21(40/60) \\
\hline
\end{tabular}

*-XX or $\mathrm{XY}$.

Table III-Signal distributions after FISH with CB21 $\mathrm{cl}$ in 78 uncultured amniotic fluid samples

\begin{tabular}{|c|c|c|c|c|c|c|c|}
\hline \multirow{2}{*}{$\begin{array}{l}\text { No. } \\
\text { of cases }\end{array}$} & \multicolumn{6}{|c|}{ Mean percentage (range) of nuclei showing 1-6 signals } & \multirow[b]{2}{*}{ Karyotype } \\
\hline & 1 & 2 & 3 & 4 & 5 & 6 & \\
\hline 72 & $\begin{array}{c}8 \\
(0-30)\end{array}$ & $\begin{array}{c}89 \\
(70-100)\end{array}$ & $\begin{array}{c}3 \\
(0-18)\end{array}$ & 0 & 0 & 0 & Disomy $21^{*}$ \\
\hline 3 & $\begin{array}{c}4 \\
(0-8)\end{array}$ & $\begin{array}{c}26 \\
(10-38)\end{array}$ & $\begin{array}{c}68 \\
(52-86)\end{array}$ & $\begin{array}{c}2 \\
(0-4)\end{array}$ & 0 & 0 & $47,--\dagger,+21$ \\
\hline 1 & 0 & 33 & 67 & 0 & 0 & 0 & $69, \mathrm{XXX}$ \\
\hline 1 & 4 & 8 & 88 & 0 & 0 & 0 & $46, X X, t(21 q 21 q)$ \\
\hline$i$ & 0 & 23 & 35 & 19 & 11 & 13 & $\begin{array}{l}\text { Mos } 46, X Y / 47, X Y,+\operatorname{dic}(21)(q 11) / 48, X Y \\
\quad+\operatorname{dic}(21)(q 11),+\operatorname{del}(21)(q 11)(25 / 21 / 54)\end{array}$ \\
\hline
\end{tabular}

*Aneuploidy of other chromosomes not mentioned. $\dagger-X X$ or $X Y$.

different karyotypes with marker (mar) chromosomes: $46, \mathrm{XY} / 47, \mathrm{XY},+\operatorname{mar} 1 / 48, \mathrm{XY},+\operatorname{mar} 1,+\operatorname{mar} 2$ (25 per cent/21 per cent/54 per cent). FISH on metaphases of this case identified marl as a dicen- tric chromosome $21 \quad(\operatorname{dic}(21)(\mathrm{pter} \rightarrow \mathrm{q} 11: \mathrm{q} 11 \rightarrow$ pter)) showing two signals with CB2lc1, and mar2 as a deleted chromosome $21(\operatorname{del}(21)(q 11 \rightarrow q$ ter $))$ showing only one signal (Fig. 1f). 

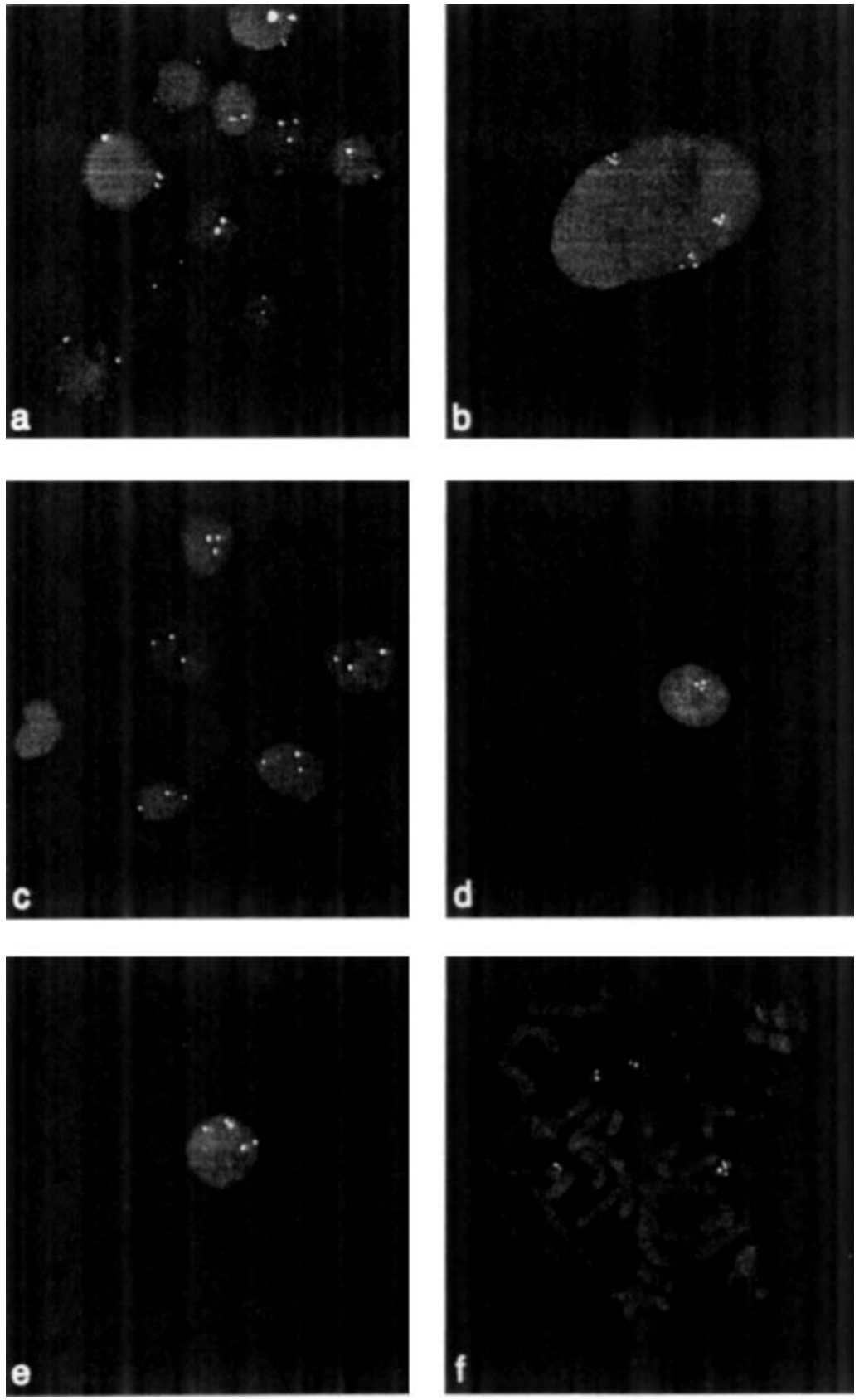

Fig. 1-FISH with the 2lq11-specific probe CB21c1. (a) Interphase lymphocytes of a mosaic trisomy 21 case showing two and three signals. (b) Interphase lymphocyte showing three signals, each consisting of separate spots produced by each of the three cosmids. (c) Uncultured amniocytes showing three signals in a case of full trisomy 21 and (d) a de novo unbalanced translocation (21q21q). (e) Uncultured amniocyte and (f) metaphase showing five signals in a case with two normal chromosomes 21 and an extra $\operatorname{del}(21)(q 11)$ and $\operatorname{dic}(21)(q 11)$ 


\section{DISCUSSION}

Several types of chromosome 21-specific probes have been investigated for interphase cytogenetics: chromosome 21-specific libraries (Pinkel et al, 1988; Lichter et al., 1988; Kuo et al., 1991), plasmid clones (Lichter et al., 1988), YACs (Bryndorf et al., 1992), Alu-PCR YACs (Romana et al., 1993; Bryndorf et al., 1994), single cosmids (Lichter et al., 1989), and cosmid contigs (Klinger et al., 1992; Ried et al., 1992; Ward et al., 1993; Spathas et al., 1994).

We investigated the utility of the present 21-probe CB21c1, consisting of three nonoverlapping cosmids, for interphase cytogenetics. We preferred to use a mixture of these probes because their joint signal was brighter than that produced by the individual cosmids. Separate spots per signal produced by each of the three non-overlapping cosmids were only occasionally encountered in the largest cultured lymphocytes (Fig. 1b), but were never observed in uncultured cells.

Zheng et al. (1992), using a cosmid contig on uncultured amniocytes, reported that more than 80 per cent of the cells in amniotic fluid are degenerate squamous epithelial cells, which are unsuitable for FISH analysis. According to Spathas et al. (1994), this problem may be solved by coating the slides with 3 '-aminopropyltriethoxysilane, which results in high quality preparations with the majority of cells showing hybridization signals. However, they also mention that the gestation time may influence the quality of the slides. This is in agreement with our results, as a large proportion of amniocytes in most samples of relatively late gestational age did not show any signals. However, in our experience this problem is mainly restricted to cosmid probes and to a lesser degree to centromeric probes.

With CB21c1, we correctly diagnosed all cases of trisomy 21. Moreover, despite its localization in $21 q 11$ instead of in the Down-specific region (21q22), we detected a Robertsonian translocation (21q21q) in uncultured amniocytes in which two of the three signals were situated in close proximity to each other in the interphase nucleus. However, these paired spots could easily be distinguished from the twin spots due to DNA replication in G2 cells. As free trisomy 21 and Robertsonian translocations of chromosome 21 make up 97 per cent and 3 per cent, respectively, of all cases of Down syndrome investigated during a 10 -year period in our postnatal cytogenetic laboratory, CB21c1 is able to detect all cases of Down syndrome at the interphase level. Only an exceptional case showing an unbalanced reciprocal translocation of chromosome 21 with breakpoints distal to 21 q11 cannot be identified with the present probe, but only with a probe from the Down region. CB21c1 could also detect an extra dicentric and deleted chromosome 21 in a rare prenatal mosaic case. Both marker chromosomes lacked the Down-specific region and would have gone undetected if a probe had been applied mapping to 21q22 such as those used by other investigators (Zheng et al., 1992; Klinger et al., 1992; Ried et al, 1992; Ward et al., 1993; Spathas et al., 1994). In order to minimize the risk of a misdiagnosis in further studies, we suggest the hybridization of both CB21cl and a probe derived from the Down syndrome region.

In five cases of uncultured amniocytes, most nuclei showed three signals, indicating the presence of three copies of chromosome 21 in the fetus. In two of these cases, a differential diagnosis of triploidy and of an unbalanced translocation ( $21 \mathrm{q} 21 \mathrm{q})$ could be made. In the first case, triploidy was expected since in addition to CB21c1, chromosome 18-, X-, and Y-specific probes were routinely applied to all amniotic fluid samples, and three signals were found in the majority of the cells after hybridization with CB21c1 as well as with the 18 and X-specific probes. In the second case, FISH was performed for verification of a de novo $\mathrm{t}(21 \mathrm{q} 21 \mathrm{q})$ in previous direct chorionic villi. The presence of three signals in most nuclei, with two signals in close proximity, confirmed the presence of the $t(21 q 21 q)$ in fetal cells.

Five mosaic cases involving trisomy 21 in lymphocytes and tetrasomy/pentasomy of the $21 \mathrm{q} 11$ region in uncultured amniocytes could be identified with the present probe. However, the level of mosaicism in interphase nuclei did not always match that in cultured cells, which in some cases might be explained by selection during cell culturing. Theoretically, the detection of a low level of mosaicism with FISH on interphase nuclei will be difficult because of the broad range of nuclei exhibiting two and three signals.

FISH on uncultured amniocytes has the potential for a rapid prenatal diagnosis of the most common chromosome abnormalities. However, it does not allow the detection of chromosome aberrations other than those detected by the probes that are commonly used (in our laboratory for chromosomes $18,21, \mathrm{X}$, and $\mathrm{Y}$ ). At this moment, 
we use the technique as an adjunct test in two prenatal instances: firstly, for the verification in amniotic fluid cells of a specific chromosome aberration previously detected in chorionic villi and potentially confined to the placenta, and, secondly, for the rapid detection of the most common chromosome abnormalities (trisomy 21 , trisomy 18 , triploidy, and $45, X$ ) in pregnancies complicated by fetal anomalies detected by ultrasound. A normal FISH result in these particular cases is always complemented by a full cytogenetic analysis of the cultured cells. An abnormal FISH result alone cannot be the basis for irreversible therapeutic action. However, interphase FISH can complement ultrasound findings and previously detected abnormalities in chorionic villi and provide help in counselling procedures.

In our experience, probe $\mathrm{CB} 21 \mathrm{c} 1$, which could detect aneuploidies as well as some unbalanced structural rearrangements of chromosome 21 , contributes to the detection of the most common abnormality in clinical cytogenetics.

\section{ACKNOWLEDGEMENTS}

We are grateful to Professor Dr C. Van Broeckhoven for providing us with the chromosome 21 cosmids (ICRFc102B02134, ICRFc102B11128, ICRFc102C0755), to Dr B. Oostra for supporting the preparation and hybridization of the cosmid DNA, to PSI (Chester, U.K.) for financing the colour plate, and to Professor Dr H. Galjaard for his continuous support. We thank Armando Braat for technical assistance in generating Fig. 1.

\section{REFERENCES}

Bryndorf, T., Christensen, B., Philip, J., Hansen, W., Yokobata, K., Bui, N., Gaiser, C. (1992). New rapid test for prenatal detection of trisomy 21 (Down's syndrome): preliminary report, Br. Med. J., 304, 1536-1539.

Bryndorf, T., Christensen, B., Xiang, Y., Philip, J., Yokobata, K., Bui, N., Gaiser, C. (1994). Fluorescence in situ hybridization with a chromosome 21-specific cosmid contig: 1-day detection of trisomy 21 in uncultured mesenchymal chorionic villus cells, Prenat. Diagn., 14, 87-96.

Cacheux, V., Tachdjian, G., Druart, L., Oury, J.F., Sérero, S., Blot, P., Nessmann, C. (1994). Evaluation of $\mathrm{X}, \mathrm{Y}, 18$, and 13/21 alpha satellite DNA probes for interphase cytogenetic analysis of uncultured amniocytes by fluorescence in situ hybridization, Prenat. Diagn., 14, 79-86.
Devilee, P., Cremer, T., Slagboom, E., Bakker, E., Scholl, H.P., Hager, H.D., Stevenson, A.F.G., Cornelisse, C.J., Pearson, P.L. (1986). Two subsets of human alphoid repetitive DNA show distinct preferential localization in the pericentric regions of chromosomes 13, 18, and 21, Cytogenet. Cell Genet., 41, 193-201.

Gänshirt-Ahlert, D., Börjesson-Stoll, R., Burschyk, M., Dohr, A., Garritsen, H.S.P., Helmer, E., Miny, P., Velasco, M., Walde, C., Patterson, D., Teng, N., Bhat, N.M., Bieber, M.M., Holzgreve, W. (1993). Detection of fetal trisomies 21 and 18 from maternal blood using triple gradient and magnetic cell sorting, Am. J. Reprod. Immunol., 30, 194-201.

Klinger, K., Landes, G., Shook, D., Harvey, R., Lopez, L., Locke, P., Lerner, T., Osathanondh, R., Leverone, B., Houseal, T., Pavelka, K., Dackowski, W. (1992). Rapid detection of chromosome aneuploidies in uncultured amniocytes by using fluorescence in situ hybridization (FISH), Am. J. Hum. Genet, , 51, 55-65.

Kuo, W.L., Tenjin, H., Segraves, R., Pinkel, D., Golbus, M.S. (1991). Detection of aneuploidy involving chromosomes 13,18 , or 21 , by fluorescence in situ hybridization (FISH) to interphase and metaphase amniocytes, Am. J. Hum. Genet., 49, 112-119.

Lebo, R.V., Flandermeyer, R.R., Diukman, R., Lynch, E.D., Lepercq, J.A., Golbus, M.S. (1992). Prenatal diagnosis with repetitive in situ hybridization probes, Am. J. Med. Genet., 43, 848-854.

Lichter, P., Cremer, T., Chang Tang, C.J., Watkins, P.C., Manuelidis, L., Ward, D.C. (1988). Rapid detection of human chromosome 21 aberrations by in situ hybridization, Proc. Natl. Acad. Sci. USA, 85, 9664 9668.

Lichter, P., Jauch, A., Cremer, T., Ward, D.C. (1989). Detection of Down syndrome by in situ hybridization with chromosome 21 specific DNA probes. In: Patterson, D., Epstein, C.J. (Eds). Molecular Genetics of Chromosome 21 and Down Syndrome, New York: Wiley-Liss, 69-78.

Mizunoe, T., Young, S.R. (1992). Low fluorescence alpha satellite region yields negative result, Prenat. Diagn., 12, 549.

Munné, S., Weier, H.U.G., Grifo, J., Cohen, J. (1994). Chromosome mosaicism in human embryos, Biol. Reprod., 51, 373-379.

Pinkel, D., Landegent, J., Collins, C., Fuscoe, J., Segraves, R., Lucas, J., Gray, J. (1988). Fluorescence in situ hybridization with human chromosome-specific libraries: detection of trisomy 21 and translocations of chromosome 4, Proc. Natl. Acad. Sci. USA, 85, 91389142.

Rao, P.N., Hayworth, R., Cox, K., Grass, F., Pettenati, M.J. (1993). Rapid detection of aneuploidy in uncultured chorionic villus cells using fluorescence in situ hybridization, Prenat. Diagn., 13, 233-238.

Ried, T., Landes, G., Dackowski, W., Klinger, K., Ward, D.C. (1992). Multicolor fluorescence in situ 
hybridization for the simultaneous detection of probe sets for chromosomes $13,18,21, X$ and $Y$ in uncultured amniotic fluid cells, Hum. Mol. Genet., 1, 307313.

Romana, S.P., Tachdjian, G., Druart, L., Cohen, D., Berger, R., Cherif, D. (1993). A simple method for prenatal diagnosis of trisomy 21 on uncultured amniocytes, Eur. J. Hum. Genet., 1, 245-251.

Seres-Santamaria, A., Catala, V., Cuatrecasas, E., Villanueva, R. (1993). Fluorescent in situ hybridization and Down's syndrome, Lancet, 341, 1544.

Spathas, D.H., Divane, A., Maniatis, G.M., FergusonSmith, M.E., Ferguson-Smith, M.A. (1994). Prenatal detection of trisomy 21 in uncultured amniocytes by fluorescence in situ hybridization: a prospective study, Prenat. Diagn., 14, 1049-1054.

Stinissen, P., Van Broeckhoven, C. (1991). A new (CA) repeat polymorphism at the D21S13E locus, Nucleic Acids Res., 19, 5089.

Stinissen, P., Van Hul, W., Van Camp, G., Backhovens, H., Wehnert, A., Vandenberghe, A., Van Broeckhoven, C. (1990). The pericentromeric 21 DNA marker pGSM21 (D21S13) contains an expressed HTF island, Genomics, 7, 119-122.
Van Opstal, D., Van Hemel, J.O., Sachs, E.S. (1993). Fetal aneuploidy diagnosed by fluorescence in-situ hybridization within 24 hours after amniocentesis, Lancet, 342, 802.

Verma, R., Luke, S. (1992). Variations in alphoid DNA sequence escape detection of aneuploidy at interphase by FISH technique, Genomics, 14, 113-116.

Ward, B.E., Gersen, S.L., Carelli, M.P., McGuire, N.M., Dackowski, W.R., Weinstein, M., Sandlin, C., Warren, R., Klinger, K. (1993). Rapid prenatal diagnosis of chromosomal aneuploidies by fluorescence in situ hybridization: clinical experience with 4500 specimens, Am. J. Hum. Genet., 52, 854-865.

Zahed, L., Murer-Orlando, M., Vekemans, M. (1992). In situ hybridization studies for the detection of common aneuploidies in CVS, Prenat. Diagn., 12, 483-493.

Zheng, Y.L., Ferguson-Smith, M.A., Warner, J.P., Ferguson-Smith, M.E., Sargent, C.A., Carter, N.P. (1992). Analysis of chromosome 21 copy number in uncultured amniocytes by fluorescence in situ hybridization using a cosmid contig, Prenat. Diagn., 12, 931-943. 